\title{
A Study on Positive Stone Culture and its Association with Rate of Sepsis after Urological Procedures
}

\author{
Sarita Rawat*, Vikas Verma, Naveen Saxena and Namita Garg \\ Department of Microbiology and Department of Urology, GMC Kota, India \\ *Corresponding author:
}

Keywords

Urolithiasis, Urosepsis, Stone culture

Article Info

Accepted:

10 January 2019

Available Online:

10 February 2019

\section{A B S T R A C T}

This prospective study was done to determine correlation between urine and/or stone cultures with postoperative sepsis in patients treated for renal and ureteral calculi. This prospective study was carried out in Department of Microbiology, Government medical college Kota between July 2015 and June 2016. The incidence of renal stone was more in male (N 70) (70\%) as compared with female (N 30) (30\%) i.e., in the ratio of 2:1. Urine culture was positive more in females $(63.67 \%$ in female vs. $37.32 \%$ in male approx. ratio $2: 1)$, however infected stone rates are almost similar in male and female $(64.67 \%$ in male vs. $62.60 \%$ in female). Out of 100 patients 43 cases showed infection in preoperative urine culture, while rests 57 were sterile. Similarly 64 patients were positive for stone culture and rest 36 were sterile. 28 patients had both stone and urine culture positive. Most common bacteria isolated in urine culture were E. coli, Klebsiella positive urine culture) cases. Post operatively 35\% (N 35) patient show signs of SIRS. Out of 35 patients who had sepsis 30 patients were positive for stone culture while 20 patients were positive for urine culture. The result was significant on chi square test (Observed $P$ value is 0.036). The results of this study suggest that in patients undergoing surgery for urolithiasis, stone cultures are better predictors of urosepsis than bladder urine $\mathrm{C}$ and $\mathrm{S}$. Positive stone culture may guide clinicians regarding selection of antibiotics, especially in cases of severe

\section{Introduction}

USD is an expanding problem. Approximately $10 \%$ of people will have a urinary stone during their lifetime (1). The key component in urinary stone formation is supersaturation, a process by which the concentration of substances in urine, such as calcium and oxalate, exceed the limits of their solubility (2). The bacterial contribution to USD formation has long been recognized.
Incidence of urinary tract infection in stone patients varies from $7 \%$ to $60 \%$ reported in previous studies. The predominant bacteria found in the nuclei of urinary calculi are Staphylococcus and Escherichia coli. Urea splitting organisms like Proteus, Pseudomonas and Klebsiella are under the urine alkaline and hence are known to promote stone formation in both clinical and experimental studies. These are the required conditions for the formation of magnesium 
ammonium phosphate calculi which are generally staghorn. Other bacteria like E. coli commonly observed in urinary infection are not urea splitting. (3) For study of aetiology and treatment of patients with urinary calculi it is necessary to perform urine and stone culture. Urinary tract infection and urinary stone can trigger a Systemic Inflammatory Response Syndrome (SIRS) before, during or after medical treatment (i.e. antibiotics) and/or surgical manipulation of infected urinary stones. It is believed that SIRS is due to the release of bacteria and their endotoxins from infected urinary stones, developing endotoxemia, bacteremia and urosepsis. Stone may be infected with a different organism than that infecting the bladder and urine. Low Penetration of antibiotics in the stone prevents complete eradication of urinary tract infection by conventional antibiotic therapy and thus leads to development of resistant organisms with intermittent shedding in urine. In this prospective study we shall determine the correlation between different sites of urine sampling, including stones.

\section{Materials and Methods}

This prospective study was carried out in Department of Microbiology, Government medical college Kota between July 2015 and June 2016.

Patients with urogenital malignancy, others cause of sepsis and those who were severely immunocompromised were excluded from the study. Before giving antibiotic treatment preoperative mid-stream sample of urine was collected in sterile container after cleaning the external genital organs. Samples were inoculated using calibrated (4mmdia.) loop on blood agar and MacConkeys agar. Cultures were incubated at $37^{\circ} \mathrm{C}$ for 24 hours. Also microscopy and Gram stain of urine samples were performed. 3-7If no growth observed after 24 hours of incubation samples were considered sterile. The identification of bacterial isolate was done by using standard biochemical test. Antibiotic sensitivity was done by using disc diffusion (Kirby and Baur) method. The sensitivity of organisms to antibiotics will be studied (Ampicillin, chloramphenicol, tetracyclin, floroquinolones, cephalosporin group of antibiotics, imepenem, meropenem aminoglycosides, macrolide group of antibiotics, linezolid etc. Urinary calculus was collected after the operation in a sterile container. Culture of calculus by giving 4-5 washes and finally by crushing the calculus in sterile mortar and pestle with $5 \mathrm{ml}$ in sterile saline, The crushed calculi core was cultured in $5 \mathrm{ml}$ thioglycolate broth which was incubated at $37^{\circ} \mathrm{C}$ for $18-24$ hours, and then subcultures were made on blood agar and Mac Conkey's agar plate for isolation of etiological agents $(9,10,11)$. Cultures were incubated at $37^{\circ} \mathrm{C}$ for 24 hours. The growth from culture plates were examined for number of colonies. The identification of bacterial isolates was done by conventional methods. Also the antibiotic sensitivity of bacterial isolates was done by using disc diffusion (Kirby Baur) method (8)

\section{Results and Discussion}

Total 100 cases of urolithiasis were enrolled in this study out of which70 were male and 30 were female.

Out of 100 patients observed 43 cases showed infection in preoperative urine culture, while rest 57 were urine culture sterile. Similarly 64 patients were positive for stone culture and rest 36 were sterile. 28patients had both stone and urine culture positive.

Urine culture was positive more in females (63.67\% in female vs. $37.32 \%$ in male approx. ratio 2:1), however infected stone rates are almost similar in male and female (64.67\% in male vs. $62.60 \%$ in female). 
Most common bacteria isolated in urine culture were E. coli (24.44\%), Klebsiella (17.77\%), Pseudomonas (13.33\%) coagulase negative Staphylococcus (17.77 and Enterococcus $8.88 \%$ ), etc.

\section{Preoperative urine culture results}

Most of the bacteria isolated from urine culture were resistant to all antibiotics (32.33\%), 33.11\% of these showed sensitive to carbapenem group of antibiotics, $25.67 \%$ to third generation cephalosporin, $21 \%$ to floroquinolons and $17.71 \%$ to aminoglycosides.

The comparison of micro-organisms isolated from pre-operative urine, showed that E. coli was predominant whereas from predominant organism isolated from crushed stone core culture was Klebsiella.

Most of these organisms (40\%) were resistant to all antibiotic, $36 \%$ show sensitivity to carbapenem group of antibiotic, $16 \%$ to 3 rd generation cephalosoprins, $12 \%$ to floroquinolons and $10 \%$ to aminoglycosides

Stone culture was done in all 100 cases, out of which $64 \%$ of stone were culture positive. In 20 patients previous urine culture was positive and in remaining 24 patients previous urine culture was negative (only stone culture positive).

Post operatively 35\% (N 35) patient show signs of SIRS. Out of which 30 were stone core culture positive. 20 Patients had urine culture positivity. $\mathrm{p}$ value was significant in for both urine and stone culture.

Bacteria and USD are clinically associated because they often occur in the same patients and USD patients often have positive urine and/or stone cultures. Antibiotics prophylaxis has been done in accordance with European Association of Urology (modified from
Infectious Diseases Society of America, and European Society of Clinical Microbiology and Infectious Diseases) guidelines.12 Urosepsis and shock have been found to occur in direct proportion to the duration of the procedure, urine bacterial load, severity of obstruction by stone and infection in the stone. 13 O'Keefe et al., retrospectively reviewed a series of 700 patients undergoing upper tract manipulation. 14 Rao et al., observed minor forms of septicemia in $37 \%$ of 27 patients undergoing PCNL. 15

Our study was conducted on 100 patients of urolithiasis which include identification of causative micro-organisms from preoperative urine and crushed stone core culture.

In our study we found that infected urine is more common in females as compared to male (approx. ratio 2:1). However infected stone rates are almost similar. The higher incidence of renal stones in males in comparison to females may be due to higher serum testosterone level favours increased endogenous oxalate production by liver which in turn predisposes to oxalate stone formation. Moreover, increased urinary citrate concentration in females may help in protection against calcium urolithiasis.16

Increased incidence of recurrent urinary tract infection in females is due to close proximity of urethra to anus, short urethra and sexual activity additionally serves to increase chance of bacterial contamination of female urethra. The pregnancy causes anatomical and hormonal changes that favour development of urinary tract infection. A change in genitourinary tract mucosa due to menopause may play a role in colonization of the introit us by coliforms, a major background factor for recurrent bladder infection in females. 17

In our study urinary stones were mainly observed in kidney (64\%) and urinary bladder $(21 \%)$ as compared to stones in ureter $(15 \%)$. 
Baron, Peterson et al., 17 found that $82.97 \%$ kidney stones were found to be sterile on culture whereas in urinary bladder, infection stones were more frequent $(48.57 \%)$. High rates of kidney stones are present as it acts as the first barrier filter for crystals and the damaging tubular epithelium which acts as nidus for stone formation.

In our study Urine cultures were positive in $43 \%$ of patients. Whereas in a study by
Bratell et al., who reported $60 \%$ of patients with positive urine cultures.18. In present study E. coli $(27 \%)$ is predominant isolated organism from urine culture. It correlates well with Jennis et al., they found E. coli (25.7\%). In present study Klebsiella (49.23\%) was most frequently isolated from stone culture. Whereas in a study by Gault et al., Pseudomonas was the predominant isolate.19 In a study by Songra et al., (20) Pseudomonas was the predominant isolate.

Table.1 Distribution of patients with urolithiasis

\begin{tabular}{|l|l|}
\hline Type of urolithiasis & No. of patients \\
\hline Renal stone & 30 \\
\hline Pelvic stone (Staghorn) & 34 \\
\hline Ureteic stone & 13 \\
\hline Vesical stone & 23 \\
\hline Total & 100 \\
\hline
\end{tabular}

Table.2 Results of urine and stone culture

\begin{tabular}{|l|c|c|c|}
\hline Specimen & Positive & Negative & P value \\
\hline $\begin{array}{l}\text { Preoperative urine } \\
\text { culture }\end{array}$ & 43 & 57 & $<0.05$ significant \\
\hline $\begin{array}{l}\text { Post-operative } \\
\text { stone core culture }\end{array}$ & 64 & 36 & \\
\hline
\end{tabular}

Table.3 showing various organism isolated from preoperative urine culture

\begin{tabular}{|l|l|}
\hline Organism & $\begin{array}{l}\text { No. of patients } \\
(\mathbf{N = 4 3 )}(\mathbf{\%})\end{array}$ \\
\hline E. coli & $12(27 \%)$ \\
\hline Klebsiella spp & $8(18.6 \%)$ \\
\hline Pseudomonas & $8(18.6 \%)$ \\
\hline CONS & $7(16.2 \%)$ \\
\hline Proteus & $4(9 \%)$ \\
\hline Enterococcus & $2(4 \%)$ \\
\hline $\begin{array}{l}\text { Citrobacter } \\
\text { frendii }\end{array}$ & $2(4 \%)$ \\
\hline
\end{tabular}


Table.4 Post-operative stone culture

\begin{tabular}{|l|l|}
\hline Organism & No. of patients (N=64) \\
\hline Klebsiella & $29(45.3 \%)$ \\
\hline Pseudomonas & $27(42.18 \%)$ \\
\hline E. coli & $21(32.8 \%)$ \\
\hline Proteus & $14(21.8 \%)$ \\
\hline CONS & $02(3 \%)$ \\
\hline Citrobacter & $01(1.5 \%)$ \\
\hline
\end{tabular}

Table.5 Comparison between urine and stone culture and occurrence of sepsis

\begin{tabular}{|l|l|l|l|l|}
\hline $\begin{array}{l}\text { Name of } \\
\text { specimen }\end{array}$ & $\begin{array}{l}\text { Total No. } \\
\text { of } \\
\text { patients }\end{array}$ & $\begin{array}{l}\text { Sepsis } \\
\text { present }\end{array}$ & $\begin{array}{l}\text { Sepsis } \\
\text { absent }\end{array}$ & P value \\
\hline $\begin{array}{l}\text { Stone culture } \\
\text { positive }\end{array}$ & 64 & 30 & 34 & $\begin{array}{l}\text { P value }<0.05, \\
\text { significant }\end{array}$ \\
\hline $\begin{array}{l}\text { Stone culture } \\
\text { negative }\end{array}$ & 36 & 05 & 31 & \\
\hline $\begin{array}{l}\text { Urine culture } \\
\text { positive }\end{array}$ & 43 & 20 & 23 & $\begin{array}{l}\text { P value }<0.05, \\
\text { significant }\end{array}$ \\
\hline $\begin{array}{l}\text { Urine culture } \\
\text { negative }\end{array}$ & 57 & 15 & 42 & \\
\hline
\end{tabular}

Table.6 Culture in patients of sepsis

\begin{tabular}{|l|l|l|l|}
\hline CULTURE & Sepsis present & Sepsis absent & P value \\
\hline STONE & 30 & 05 & $\begin{array}{l}\text { P value }<0.05, \\
\text { significant }\end{array}$ \\
\hline URINE & 20 & 15 & \\
\hline
\end{tabular}

In a similar study of 328 patients Jairam R. Eswara and Ahmad Sharif et al., found that $3 \%(11 / 328)$ developed postoperative sepsis. $73 \%(8 / 11)$ had positive stone cultures.

While none had a positive preoperative urine culture. $8 \%(8 / 96)$ with positive stone cultures and $1 \%(3 / 232)$ with negative stone cultures developed sepsis $(\mathrm{P}=0.003)$.

These results suggest that stone culture is more informative than preoperative urine culture for determining treatment of postoperative sepsis. 21
In conclusion, the results of this study suggest that in patients undergoing surgery for urolithiasis, stone cultures are better predictors of urosepsis than bladder urine C\&S. Many times urine C\&S may be negative or stones may be infected with different organism, in such cases positive stone culture may guide clinicians regarding selection of antibiotics, especially in cases of severe life threatening urosepsis.

Funding: No funding sources

Conflict of interest: None declared 
Ethical approval: The study was approved by the institutional ethics committee

\section{References}

1) Pak CY. Kidney stones. Lancet 1998; 351: 1797-801. $10.1016 / \mathrm{S} 0140-$ 6736(98)01295-1

2) Coe FL, Parks JH, Asplin JR. The pathogenesis and treatment of kidney stones. N Engl J Med1992; 327: 114152. 10.1056/NEJM199210153271607

3) Asha T. Kore, Gurjeet Singh, S. G. Pawar. Bacteriological profile of urine in patients with urinary calculi. Indian $\mathbf{J}$ Appl Res. 2013 Aug;3(8):600-1.

4) Joel Gustavo et al., Infected urinary stones, endotoxins and urosepsis. In: Ahmad Nikibakhsh eds. Clinical Management of Complicated Urinary Tract Infection. 4th ed. Europe: InTech; 2011.

5)Bratell S, Brorson JE, Grenabo L, Hedelin $\mathrm{H}$, Petterson S. The bacteriology of operated renal stones. Eur Urol. 1990; 17:58-61. 6

6) Dewan B, Sharma M, Nayak N, Sharma SK. Upper urinary tract stones and Ureaplasma urealyticum. J Med Res. 1997; 107: 15-21.

7) Gault MH, Longerich LL, Crane G, Cooper R, Dow D, Best L, et al., Bacteriology of urinary tract stones. J Urol. 1995; 153: 1164-70.

8) Ananthanarayan R, Jayaram Panikar CK. Textbook of microbiology. In: Ananthanarayan R, Jayaram Panikar CK, eds. A Book. 5th ed. Hyderabad, India: Sangam Books Ltd; 1996

9) Jennis F, Lavan JN, Neale FC, Posen S. Staghorn calculi of the kidney, clinical, bacteriological and biochemical features. Brit J Urol. 1970; 42: 511-8.

10) Chakrabarty PA. A textbook of microbiology. In: Chakrabarty PA, eds. A Book. 1st ed. India: NCBA Publisher; 1998.
11). Hugosson J, Grenabo L, Hedelinm H, Pettersson S. and Seebergs bacteriology of urinary tract stones. J Urol. 1990; 143: $965-8$.

12) European Association of Urology (EAU). Guidelines on urinary tract infection, 2001. Available at: www.uroweb.org. Accessed December 2003.

13) Stamey TA. Urosepsis and shock. In: Stamey TA, eds. Pathogenesis and Treatment of Urinary Tract Infections. 1st ed. Baltimore: Williams \& Wilkins Co.; 1980: 430.

14. O'Keeffe KoeSbook PRoPN. Severe sepsis following percutaneous or endoscopic procedures for urinary tract stones. Br J Urol. 1993; 72: 277.

15. Rao PN, Dube DA, Weightman NC, Oppenheim BA, Morris J. Prediction of septicemia following endourological manipulation for stones in the upper urinary tract. J Urol. 1991; 146:955.

16. Welshman SG, McGeown MG. The relationship of urinary cations: calcium, magnesium sodium, and potassium in patients with renal calculi. Br J Urol. 1975; 47: 237-42.

17. Welshman SG, McGeown MG. The relationship of urinary cations: calcium, magnesium sodium, and potassium in patients with renal calculi. Br J Urol. 1975; 47: 237-42.

18. Bratell S, Brorson JE, Grenabo I, Hedelin R, Pettersons S. Bacteriology of operated renal stones. Eur Urol. 1990; 17: 58.

19.Gault MH, Longerich LL, Crane G, Cooper R, Dow D, Best L, et al., Bacteriology of urinary tract stones. $\mathrm{J}$ Urol. 1995; 153: 1164-70.

20) Songra MC, Damor $M$, Namdev RK, Patbamaniya NK, Nawalakhe P, Jain R. A study on positive stone culture and its association with rate of sepsis after urological procedures. Int Surg J 2015; 2: 239-46. 
21. Jairam R. Esawa, Ahmad Sharif-Tabrizi, Dianne Sacco. Positive stone culture is after endourological procedures. associated with a higher rate of sepsis Urolithiasis. 2013 October; 41(5): 4114.

\section{How to cite this article:}

Sarita Rawat, Vikas Verma, Naveen Saxena and Namita Garg. 2019. A Study on Positive Stone Culture and its Association with Rate of Sepsis after Urological Procedures. Int.J.Curr.Microbiol.App.Sci. 8(02): 1015-1021. doi: https://doi.org/10.20546/ijcmas.2019.802.118 